\title{
Steroid hormone abnormalities in women with severe idiopathic constipation
}

\author{
M A Kamm, M J G Farthing, J E Lennard-Jones, L A Perry, T Chard
}

Department of

Gastroenterology, St

Mark's Hospital, London

M A Kamm

$M$ J G Farthing

J E Lennard-Jones

Reproductive Physiology,

St Bartholomew's

Hospital, London

L A Perry

T Chard

Correspondence to:

Hospital, City Road, London ECIV 2PS.

Accepted for publication

5 March 1990
Department of

Dr M Kamm, St Mark's

\begin{abstract}
Patients with severe idiopathic constipation are almost exclusively women of reproductive age. To investigate the possibility of a sex hormone abnormality in this condition, we have compared a range of sex hormones during the follicular and luteal phases of the menstrual cycle in 23 healthy women (mean age 33 years) with those in 26 patients with severe idiopathic constipation (mean age 32 years, spontaneous bowel frequency less than one per week). In the patients there was a reduction in the follicular phase of progesterone (4.5 $v$ $4 \mathrm{nmol} / \mathrm{l}, \mathrm{p}=0.006$, median value, controls $v$ patients), 17 hydroxyprogesterone (9.7 $v 5.8$ $\mathrm{nmol} / \mathrm{l}, \mathrm{p}=0.01$ ), cortisol (387 v $245 \mathrm{nmol} / \mathrm{l}$, $\mathrm{p}=0.008)$, testosterone $(2.3$ v $1.8 \mathrm{nmol} / \mathrm{l}$, $\mathrm{p}<0.001)$, androstenedione $(10.3 v 8.4 \mathrm{nmol} / \mathrm{h}$, $\mathbf{p}=0.02$, and dehydroepiandrosterone sulphate $(5.1 v 3.0 \mu \mathrm{mol} / 1, \mathrm{p}=0.03)$. In the luteal phase there was a reduction of oestradiol (483 $v 350 \mathrm{pmol} / \mathrm{h}, \mathrm{p}=0.015)$, cortisol (322 v 242 $\mathrm{nmol} / \mathrm{l}, \mathrm{p}=0.047)$, and testosterone $(2.4 v 1.7$
\end{abstract}

Sex hormone concentrations in healthy control women and women with severe idiopathic constipation

\begin{tabular}{|c|c|c|c|c|c|c|}
\hline \multirow[b]{2}{*}{ Hormone } & \multicolumn{3}{|c|}{ Follicular phase } & \multicolumn{3}{|c|}{ Luteal phase } \\
\hline & Controls & Patients & pvalue & Controls & Patients & pvalue \\
\hline \multirow{11}{*}{ 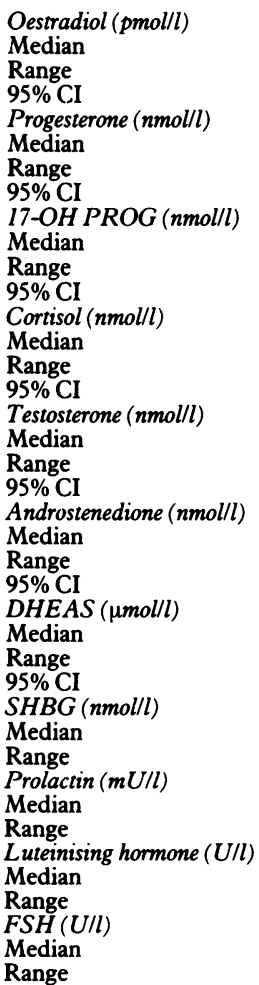 } & $\begin{array}{l}135 \\
40-460\end{array}$ & $\begin{array}{l}123 \\
74-420\end{array}$ & NS & $\begin{array}{l}483 \\
145-866\end{array}$ & $\begin{array}{l}350 \\
138-617 \\
-275\end{array}$ & 0.015 \\
\hline & $\begin{array}{l}4 \cdot 5 \\
4-11\end{array}$ & $\begin{array}{c}4 \cdot 0 \\
2 \cdot 2^{4-12 \cdot 5}\end{array}$ & 0.006 & $\begin{array}{c}38 \cdot 8 \\
4-89\end{array}$ & $\begin{array}{c}36 \cdot 4 \\
4-86\end{array}$ & NS \\
\hline & $\begin{array}{l}9 \cdot 7 \\
4 \cdot 3-26 \\
\quad 0\end{array}$ & $\begin{array}{l}5 \cdot 8 \\
3 \cdot 2-13 \\
-6 \cdot 5\end{array}$ & 0.01 & $\begin{array}{l}11 \cdot 1 \\
7 \cdot 0-18 \cdot 7\end{array}$ & $\begin{array}{l}15 \cdot 5 \\
6 \cdot 2-23 \cdot 5\end{array}$ & NS \\
\hline & $\begin{array}{l}387 \\
135-840\end{array}$ & $\begin{array}{l}245 \\
150-610 \\
-215\end{array}$ & 0.008 & $\begin{array}{l}332 \\
197-553\end{array}$ & $\begin{array}{l}242 \\
92-455 \\
-132\end{array}$ & 0.047 \\
\hline & $\begin{array}{l}2 \cdot 3 \\
1 \cdot 7-3 \cdot 4 \\
\end{array}$ & $\begin{array}{l}1 \cdot 8 \\
0 \cdot 8-2 \cdot 7 \\
-1 \cdot 0\end{array}$ & $<0.001$ & $\begin{array}{r}2 \cdot 4 \\
1 \cdot 5-3 \cdot 5 \\
0\end{array}$ & $-1 \cdot 0^{1 \cdot 0^{-}-2 \cdot 9}$ & 0.003 \\
\hline & $\begin{array}{l}10 \cdot 3 \\
5 \cdot 6-19 \cdot 5 \\
0\end{array}$ & $\begin{array}{l}8 \cdot 4 \\
6 \cdot 0-18 \cdot 6\end{array}$ & 0.02 & $\begin{array}{l}9 \cdot 8 \\
5 \cdot 5-18 \cdot 3\end{array}$ & $\begin{array}{l}8 \cdot 3 \\
6 \cdot 0-15 \cdot 7\end{array}$ & NS \\
\hline & $\begin{array}{l}5 \cdot 1 \\
3 \cdot 6-20 \\
\end{array}$ & $\begin{array}{l}3 \cdot 0 \\
1 \cdot 1-7 \cdot 6 \\
2 \cdot 9^{-1}\end{array}$ & 0.03 & $\begin{array}{l}4 \cdot 7 \\
2 \cdot 4-17 \cdot 5\end{array}$ & $\begin{array}{l}3 \cdot 5 \\
1 \cdot 0-8 \cdot 2\end{array}$ & NS \\
\hline & $\begin{array}{l}68 \\
28-120\end{array}$ & $\begin{array}{l}56 \\
40-120\end{array}$ & NS & $\begin{array}{l}70 \\
30-120\end{array}$ & $\begin{array}{l}59 \\
38-100\end{array}$ & NS \\
\hline & $\begin{array}{l}245 \\
78-1151\end{array}$ & $\begin{array}{l}170 \\
60-1188\end{array}$ & NS & $\begin{array}{l}244 \\
103-1265\end{array}$ & $\begin{array}{l}182 \\
101-652\end{array}$ & NS \\
\hline & $\begin{array}{l}5 \cdot 3 \\
3 \cdot 5-50\end{array}$ & $\begin{array}{l}5 \cdot 6 \\
2 \cdot 3-18\end{array}$ & NS & $\begin{array}{l}5 \cdot 3 \\
1 \cdot 8-31 \cdot 7\end{array}$ & $\begin{array}{l}4 \cdot 6 \\
2 \cdot 4-19 \cdot 4\end{array}$ & NS \\
\hline & $\begin{array}{l}5 \cdot 1 \\
2 \cdot 5-9 \cdot 6\end{array}$ & $\begin{array}{l}4 \cdot 2 \\
1 \cdot 5-8 \cdot 2\end{array}$ & NS & $\begin{array}{l}2 \cdot 2 \\
0.8-6.7\end{array}$ & $\begin{array}{l}2 \cdot 6 \\
1 \cdot 2-4 \cdot 6\end{array}$ & NS \\
\hline
\end{tabular}

Comparisons performed between control and patient groups using Mann-Whitney U Test. Where p $<0.05$ when comparing patients and controls, the $95 \%$ confidence interval (CI) for the difference

between the two groups is presented below the range.

17-OH PROG = 17 hydroxyprogesterone; DHEAS = dehydroepiandrosterone
SHBG = sex hormone binding globulin; $\mathrm{FHS}=$ follicle stimulating hormone. nmol/l, $p=0.003)$. The concentrations of sex hormone binding globulin, prolactin, luteinising hormone, and follicle stimulating hormone were not significantly different in either phase of the cycle. Women with severe idiopathic constipation have a consistent reduction in steroid hormones.

Patients with severe idiopathic constipation and a colon of normal diameter are almost exclusively women. ${ }^{1-4}$ They are usually of reproductive age, and on questionnaire testing have a higher prevalence of painful and irregular menstruation and previous gynaecological surgery compared with an age matched group of healthy women. In one prospective study, ${ }^{5}$ however, ultrasound examination of the ovaries, uterus, and pelvic veins did not show a higher prevalence of morphological abnormalities in severely constipated women compared with a healthy control group.

The normal appearance of the reproductive system, however, does not exclude an abnormality of sex hormones. Two previous studies have raised the possibility of a hormonal disturbance in severely constipated women. ${ }^{67}$ In one, ${ }^{6}$ the concentration of serum prolactin was high in a group of constipated women, while in the other the serum prolactin value was normal but there was an increased prevalence of galactorrhoea. This study was designed to investigate in detail whether women with severe idiopathic constipation have an abnormality affecting their sex hormones.

\section{Subjects and methods}

SUBJECTS

Twenty six patients (mean age 32 years, range 14-43) with severe idiopathic constipation were studied. All had a spontaneous stated bowel frequency of less than once per week (range 1-4 weeks). Slow intestinal transit was confirmed using the radio-opaque marker method described by Hinton et al. ${ }^{8}$ No patient had episodic diarrhoea suggestive of the irritable bowel syndrome, and secondary causes of constipation had been excluded in all. All patients had a colon of normal diameter on barium enema. No patient was taking the oral contraceptive or other oral medications, although some were using selfadministered phosphate enemas or bisacodyl suppositories. Sixteen were studied in both phases of the menstrual cycle, a further nine were studied in the follicular phase alone, and one in the luteal phase alone. All except two patients experienced regular menstrual cycles.

Twenty three healthy women (mean age 33 
years, range 22-47) were studied as control subjects. All the control subjects had a bowel frequency ranging from $0.5-3.0$ per day. None were taking any medication and none was on the oral contraceptive. Twenty were studied during both phases of the menstrual cycle, a further two subjects were studied only in the follicular phase, and a further one subject was studied only in the luteal phase. All the control subjects experienced regular menstrual cycles.

All subjects gave informed consent to participate in the study, which was approved by the Ethical Committee of the City and Hackney Health Authority in December 1986.

\section{METHODS}

All days in the menstrual cycle were counted from the first day of menstrual bleeding (day 1). Subjects were randomly allocated to begin the study in the first or second half of the menstrual cycle. Follicular phase blood samples were taken on day 5 , and luteal phase samples were taken on days 19,21 , and 23 to be certain of documenting the adequacy of the luteal serum progesterone rise.

Samples of venous blood were taken from all subjects between 8 am and $10 \mathrm{am}$, with the subject fasted from the previous evening. Blood samples were allowed to stand till clotted, then they were centrifuged and the serum stored at $-20^{\circ} \mathrm{C}$. For each hormone assayed, the control and patient samples were run as a single batch.

Oestradiol, progesterone, 17 hydroxyprogesterone, cortisol, testosterone, androstenedione,

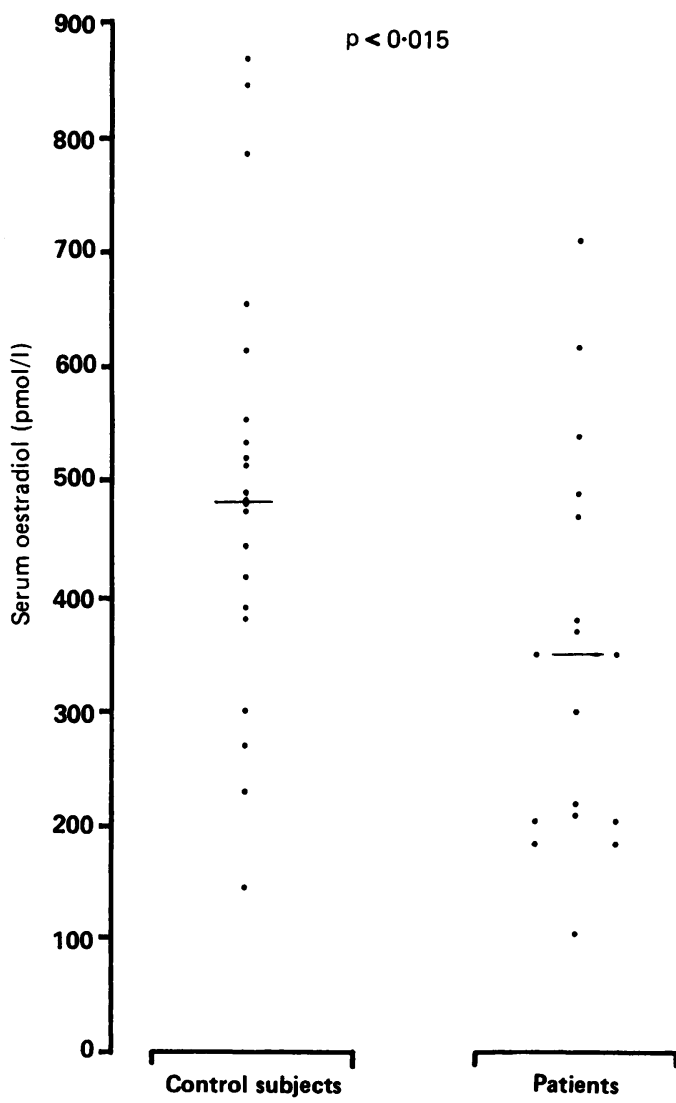

Figure 1: Serum oestradiol values in control subjects and constipated patients during the luteal phase of the menstrual cycle. Each point represents the mean of three luteal serum samples for a subject. The bar represents the median of each group. and dehydroepiandrosterone sulphate were measured by radioimmunoassay as previously published from our laboratory. ${ }^{9-13}$ Sex hormone binding globulin was measured by a competitive protein binding technique using a tritiated label. ${ }^{14}$ Luteinising hormone and follicle stimulating hormone were measured by radioimmunoassay using rabbit antisera. Prolactin was measured by radioimmunoassay using a second antibody polyethylene glycol assisted separation procedure.

\section{STATISTICAL ANALYSIS}

For each hormone the serum concentrations for control and patient groups were compared using the Mann-Whitney U test. A p value of less than 0.05 was taken to represent a significant difference between the control and patient groups. A comparison was made for each hormone for both the follicular and luteal phases. To obtain a representative value for each subject for the luteal phase the mean of the 3 luteal samples was calculated for each hormone.

\section{Results}

In both phases of the menstrual cycle there was a significantly decreased concentration of many of the steroid hormones in the patients compared with the control subjects (Table, Figs 1-4). Although there was considerable overlap

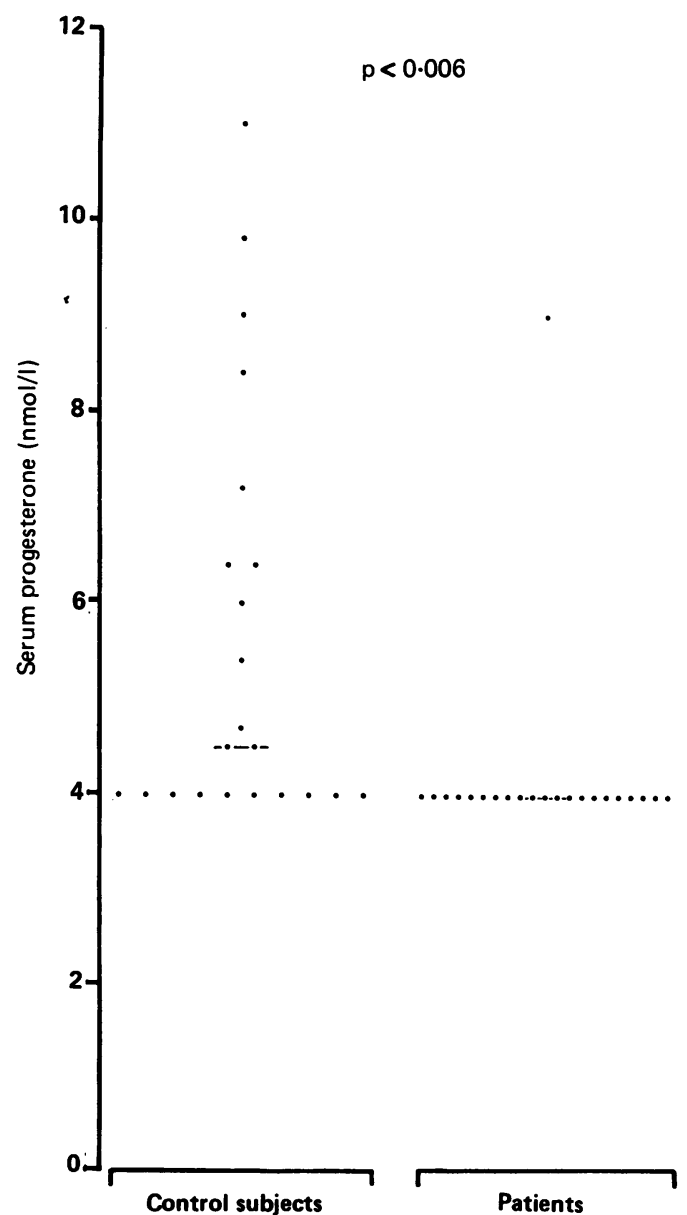

Figure 2: Serum progesterone values in control subjects and constipated patients during the follicular phase of the menstrual cycle. The lower detection limit for this assay is $4 \mathrm{nmol} / \mathrm{l} .{ }^{9}$ The bar represents the median of the control subjects. The median of the patients is $4 \mathrm{nM}$. 


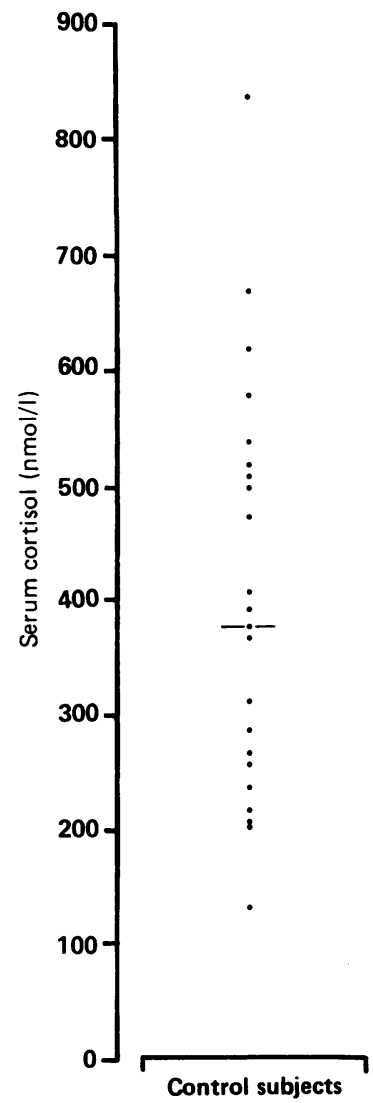

$p<0.008$

Figure 3: Morming serum cortisol value in control subjects and constipated patients measured during the follicular phase of the menstrual cycle. The bar represents the median of each group.

between the data of the controls and patients, for many hormones the patients' values were at the lower end of the spectrum.

Two of 23 control subjects and two of 17 patients had a luteal phase which was likely to be anovulatory (no rise in serum progesterone and a luteal progesterone concentration $<20 \mathrm{nmol} / \mathrm{l}^{9}$

In both phases of the menstrual cycle there was no significant difference between the control subjects' and patients' concentrations of sex hormone binding globulin, prolactin, luteinising hormone, and follicle stimulating hormone.

\section{Discussion}

This study has excluded a gross disturbance of sex hormones in women with severe constipation. It has shown, however, a significantly lower serum concentration of many of the adrenal, and to a lesser extent ovarian, steroid hormones in women with severe idiopathic constipation compared with a group of healthy age matched subjects. Although many of the hormone concentrations were decreased when the group of constipated women were considered as a whole, individual patients' hormone concentrations generally fell within the normal range. This may explain the lack of compensatory increase in luteinising hormone or follicle stimulating hormone.

The normal concentration of sex hormone binding globulin suggests that the lower concentration of steroid hormones was not related to a low serum concentration of transport proteins or a dilutional factor.

In an earlier study, ${ }^{6}$ women with severe consti-

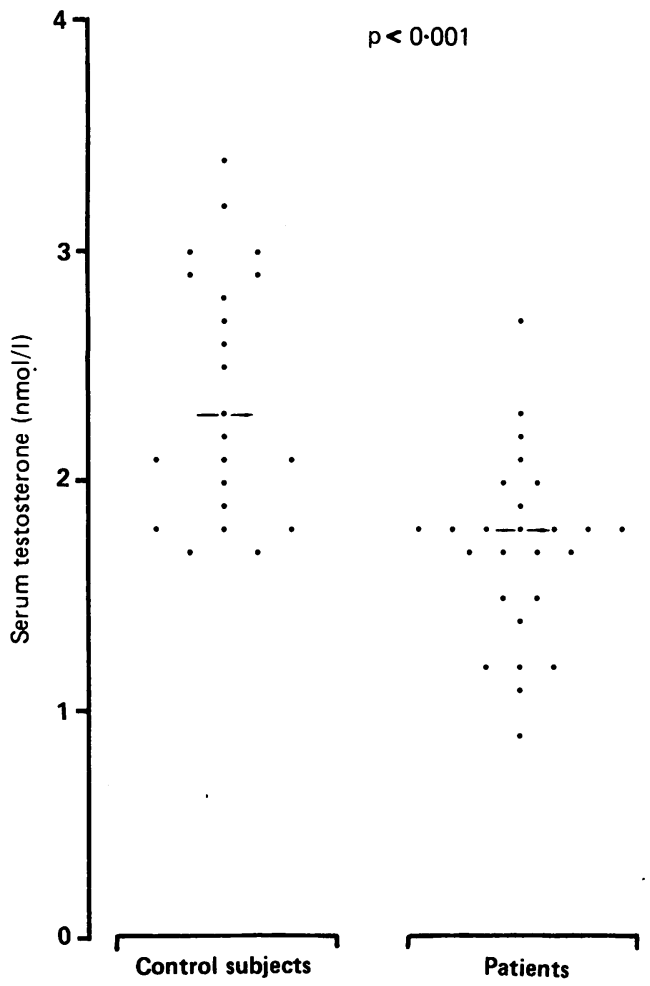

Figure 4: Serum testosterone values in control subjects and constipated patients measured during the follicular phase of the menstrual cycle. The bar represents the median of each group.

pation were found to have a higher mean serum prolactin concentration than healthy control subjects or women with the irritable bowel syndrome, but in another study ${ }^{7}$ as well as in the current study prolactin values were not raised. A low serum oestradiol concentration in severely constipated women has been noted previously. $^{6}$

The abnormalities found in this study were in hormones of adrenal and ovarian origin. Cortisol is produced exclusively by the adrenal cortex. The androgens - testosterone, androstenedione, and dehydroepiandrosterone - are produced largely by the adrenal cortex and to a limited extent by the ovaries. ${ }^{15}$ In women they have an anabolic role. Of these substances, testosterone has the most androgenic activity. ${ }^{16}$ Most of the oestradiol production in premenopausal women occurs in the ovaries. ${ }^{17}$ Progesterone was found to be decreased in concentration only during the follicular phase; this hormone is produced predominantly by the adrenal glands during the follicular phase, but during the luteal phase is mainly ovarian in origin.

The reduced concentration of these hormones suggests that their production may be decreased or their elimination increased. This could occur by several mechanisms. The steroid hormones are hydrophobic; their catabolism inactivates the active hormone while rendering it more hydrophilic. Most of this catabolism occurs in the liver and results in the formation of glucuronide and sulphate conjugates. ${ }^{18}$ These are then excreted either in the urine or the bile. Oestradiol and progesterone metabolites are largely excreted into bile, prolonging their clearance from the body, while cortisol metabolites are minimally excreted and the androgen metabolites have an intermediate biliary excretion. For example, 
after the experimental administration of intravenous oestrone or oestradiol, $23-68 \%$ of the dose can be recovered in bile. ${ }^{17}$ The concentration of individual steroids in the bile is much higher than their precursor hormones in the blood, suggesting a concentrating excretion mechanism by the hepatic cells to the biliary canaliculi.

The biliary steroid conjugates undergo hydrolysis in the distal ileum and colon by enteric bacteria and possibly by the intestinal mucosa, and are then largely reabsorbed in the unconjugated form, although some reconjugation may occur in the mucosal cells during absorption. Some of the hydrolysed substances are excreted in the faeces as free steroids. Twenty five to $30 \%$ of the secreted oestradiol seems to be excreted in the faeces. ${ }^{19}$

It is possible that in severe constipation there is an alteration in the enterohepatic circulation which affects the circulating concentrations of the steroid hormones. The small intestinal transit time tends to be longer in patients with severe constipation, although the difference is not great ${ }^{20}$ In patients with 'slow transit constipation,' however, the frequency of bowel movements may be as low as once every three or four weeks. ${ }^{1-4}$ Colonic transit is therefore greatly prolonged, with stasis of luminal contents. Although this could provide a greater opportunity for deconjugation of lumenal steroids, with increased absorption, the reverse may be true with the stationary caecal contents limiting their exposure to the colonic mucosa. Alternatively, faecal stasis may change the nature or composition of colonic bacteria, perhaps rendering them less capable of bile salt deconjugation. There is no available information about the change in colonic bacteria which occurs in patients with slow colonic transit, but drug induced prolongation of the transit time in healthy subjects does cause a decrease in the faecal bacterial mass. ${ }^{21}$ In addition, patients who have had a major part of their colon resected have low urinary oestriol values. ${ }^{22} \mathrm{~A}$ change in the composition of colonic bacteria can alter the steroid enterohepatic circulation; for example, the faecal excretion of steroids increases during the administration of antibiotics and the steroid structures more closely resemble that of bile. ${ }^{23}$

Reabsorbed metabolites may also undergo further metabolism in the intestinal wall..$^{24}$ It is possible that in constipation there is not only a disturbance of motility but also of the metabolic activity of the intestinal wall.

Care was taken to ensure that the patients in this study were not taking drugs that could interfere with steroid metabolism. This could occur via a direct effect on ovarian or adrenal production, or via an effect on hepatic uptake, enzyme induction or inhibition, or excretion. In addition, antibiotics can modify the deconjugation by enteric bacteria, while oral laxatives may affect the enterohepatic circulation of these substances.

Although the observed changes in the serum concentration of steroid hormones may be the result of constipation and an altered enterohepatic circulation, for many of the steroid hormones the biliary excretion is small. An alternative relation may exist whereby a primary abnormality of these hormones could have a direct effect on intestinal motility, although we feel this is unlikely in view of the small observed hormone changes. Although individual hormone values fell within the normal range, a reduced concentration for each patient relative to their own 'normal' concentration may be important in its metabolic effects. Oestradiol and progesterone have been extensively studied in this context, but the evidence that they play an important role in influencing gastrointestinal motility is contradictory. ${ }^{26-37}$ Whether other sex steroids are important under normal physiological circumstances for effective gastrointestinal motility is unknown. Although oestrogen, progesterone, and testosterone receptors are present in colonic mucosa, ${ }^{38}$ their presence in colonic smooth muscle or the enteric nerve plexuses has not been determined. Evidence against an important prokinetic motility role of the androgens includes the fact that constipation is not a well described component of hypogonadism in men or women. In addition, diarrhoea rather than constipation is a feature of adrenal insufficiency.

Sex hormones may influence the activity of the pelvic floor and defecatory function. Onuf's nucleus is the sacral spinal cell column which contains the motor neurones to the urethral and anal sphincters as well as the pelvic floor muscles. ${ }^{39}$ This nucleus has been found to show sexual dimorphism in rats, with a greater number and size of motor neurones in the male. In addition, testosterone was found to bind to these neurones in male rats, ${ }^{10}$ raising the possibility of a direct effect of sex hormones on central defecatory regulation.

A third possible explanation for our findings is that some extraintestinal primary pathological process results in both the motility disorder and the disturbance of steroid hormones independently.

In summary, we have observed a consistent reduction in many of the steroid hormones in women with severe idiopathic constipation. Whether the observed changes are secondary to, accompanied by, or the cause of the motility disorder deserves further investigation.

MAK is supported by the St Mark's Research Foundation. MJGF is a Wellcome Trust Senior Lecturer. The authors wish to thank Prof $L$ Rees for the determination of pituitary hormone concentrations, and Ms P Patel for assistance with the statistical analysis.

1 Preston DM, Lennard-Jones JE. Severe chronic constipation of young women: 'idiopathic slow transit constipation'. Gut 1986; $27: 41-8$.

2 Read NW, Timms JM, Barfield LJ, Donnely TC, Bannister JJ. Impairment of defecation in young women with severe constipation. Gastroenterology 1986; 90: 53-60.

3 Shouler P, Keighley MRB. Changes in colorectal function in severe idiopathic constipation. Gastroenterology 1986; 90: 414-20.

4 Reynolds JC, Ouyang A, Lee CA, Baker L, Sunshine AG Cohen S. Chronic severe constipation. Prospective motility studies in 25 consecutive patients. Gastroenterology 1987; 92: 414-20.

5 Kamm MA, McLean A, Farthing MJG, Lennard-Jones JE. Ultrasonography demonstrates no abnormality of pelvic structures in women with severe idiopathic constipation. Gut 1989; 30: 1241-3

6 Preston DM, Rees LH, Lennard-Jones JE. Gynaecological disorders and hyperprolactinaemia in chronic constipation [Abstract]. Gut 1983; 24: A480.

7 Watier A, Devroede G, Duranceau A, et al. Constipation with colonic inertia. A manifestation of colonic disease? Dig Dis Sci 1983; 28: 1025-33. 
8 Hinton JM, Lennard-Jones JE, Young AC. A new method for studying gut transit times using radio-opaque markers. Gut $1969 ; 10: 842-7$

9 Wathen NC, Perry L, Lilford RJ, Chard T. Interpretation of single progesterone measurement in diagnosis of anovulation and defective luteal phase: observations on analysis of the normal range. $\mathrm{Br} M$ ed $\mathcal{F} 1984 ; 288$ : 7-9.

10 Cunnah D, Jessop DS, Besser GM, Rees LH. Measurement of circulating corticotrophin releasing factor in man. F Endocrinol 1987; 113: 123-31

11 Wathen NC, Perry LA, Rubenstein E, Chard T. A relationship between sex hormone binding globulin and dehydroepiandrosterone sulphate in normally menstruating females. epiandrosterone sulphate in normally

12 El-Gamal BA, Landon J, Arbuknersha RA, Gallacher G, Perry LA. The production and characterisation of antisera to 17hydroxyprogesterone. F Steroid Biochem 1987; 26: 375-82.

13 Holly JMP, Smith CP, Dunger DB, et al. Relationship between the pubertal fall in sex hormone binding globulin and insulin-like growth factor binding protein. A synchronised approach to pubertal development? Clin Endocrinol 1989; 31: 277-84.

14 Fattah DI, Chard T. A simplified method for measuring sex hormone binding globulin. Clin Chem 1981; 27: 1277-9.

15 Brooks RV. Androgens: physiology and pathology. In: Makin HLJ, ed. Biochemistry of steroid hormones. Oxford: Blackwell Scientific, 1984: 565-94

16 Sommerville IF, Collins WP. In: Briggs MH, ed. Advances in steroid biochemistry and pharmacology. Vol 2. London: Academic Press, 1970: 226.

17 Fotherby K. Biosynthesis of the oestrogens. In: Makin HLJ ed. Biochemistry of steroid hormones. Oxford: Blackwel Scientific, 1984: 207-29.

18 Honour JW. Biliary excretion and enterohepatic circulation In: Makin HLJ, ed. Biochemistry of steroid hormones. Oxford: Blackwell Scientific, 1984: 382-408.

19 Adlercreutz HF, Martin F, Jarvenpaa P, Fotsis T. Steroid absorption and enterohepatic recycling. Contraception 1979; 20: 201-3.

20 Bannister JJ, Timms JM, Barfield LJ, Donnelly TC, Read NW. Physiological studies in young women with chronic NW. Physiological studies in young women

21 Stephen AM, Wiggins HS, Cummings JH. Effect of changing transit time on colonic microbial metabolism in man. Gut 1987; 28: 601-9.

22 Trolle D, Pederson SN, Gaede P. Estriol concentrations in urine and serum in patients with various intestinal diseases. Acta Obstet Gynecol Scand 1977; 56: 347-9.

23 Janne OA, Laatikainen TJ, Vihko RK. Effect of reduction of the intestinal microflora on the excretion of neutral steroids in human faeces and urine. Eur F Biochem 1971; 20: 120-3.
24 Hartiala K. Metabolism of hormones, drugs and other substances by the gut. Physiol Rev 1973; 53: 496-534.

25 Farthing MJG, Vinson GP, Edwards CRW, Dawson AM. Testosterone metabolism by the rat gastrointestinal tract, in vitro and in vivo. Gut 1982; 23: 226-34.

26 Winship DH. Gastrointestinal diseases. In: Burrow GN, Ferris TF, eds. Medical complications during pregnancy. Philadelphia: WB Saunders, 1975: 275-350.

27 VanThiel DH, Gavaler J, Joshi SN, Sara SK, Stremple J. Heartburn of pregnancy. Gastroenterology 1977; 72: 666-8.

28 Davison JS, Davison MC, Hay DM. Gastric emptying time in late pregnancy and labour. F Obstet Gynaecol Br Emp 1970; 77: 37-41.

29 Braverman DZ, Johnson ML, Kern F. Effects of pregnancy and contraceptive steroids on gall bladder function. $N E n g l$ F Med 1980; 302: 362-4

30 Wald A, Van Thiel DH, Hoechstetter L, et al. Gastrointestinal transit: the effect of the menstrual cycle. Gastroenterology 1981; 80: 1497-500.

31 Wald A, Van Thiel DH, Hoechstetter L, et al. Effect of pregnancy on gastrointestinal transit. Dig Dis Sci 1982; 27: 1015-8.

32 Gill RC, Bowes KL, Kingma YJ. Effect of progesterone on canine colonic smooth muscle. Gastroenterology 1985; 88: 1941-7.

33 Bruce LA, Behsudi FM. Progesterone effects on three regional gastrointestinal tissues. Life Sci 1979; 25: 729-34.

34 Ganiban G, Besselman D, Harcelrode J, Murthy SNS. Effect of sex steroids on total gastrointestinal transit in male rats. Gastroenterology 1985; 88: 1713 .

35 Ryan JP, Bhojwani A. Effect of ovariectomy and sex steroid hormone pretreatment on colonic transit in the rat. Gastroenterology 1985; 88: 1564

36 Turnbull GK, Thompson DG, Day S, Martin J, Walker E, Lennard-Jones JE. Relationship between symptoms, menstrual cycle and gastrointestinal transit in normal females and constipated women. Gut 1989; 30: 30-4.

37 Kamm MA, Farthing MJG, Lennard-Jones JE. Bowel function and transit rate during the menstrual cycle. Gut function and tran

38 Stebbings WSL, Farthing MJG, Anderson E, Puddyfoot JR, Vinson GP, Wood RFM. Sex steroid receptor status in colorectal cancer in relation to serum sex and pituitary hormone concentrations and survival. Gastroenterology 1987; 92: 1653

39 Schroder HD. Anatomical and pathoanatomical studies on the spinal efferent systems innervating pelvic structures. $\mathcal{F}$ Auton Nerv Syst 1985; 14: 23-48.

40 Breedlove SM, Arnold AP. Hormone accumulation in a sexually dimorphic nucleus of the rat spinal cord. Science 1980; 210: $564-6$. 